\title{
REFLECTIONS ON LYSIAS AND LYSIANIC RHETORIC IN THE FOURTH CENTURY BCE
}

The only explicit reference to Lysias in the corpus of ancient orators is made in Apollodorus' speech Against Neaira, which had long been included in the Demosthenic corpus. ${ }^{\text {I }}$ This speech, dating from around the 340s, mentions Lysias in a brief passage in connection with an argument about the background of Neaira who is accused of not being a citizen of Athens, but acting as if she was in legal marriage with an Athenian citizen. Sections $\$ \S 2 \mathrm{I}-3$ make some personal, but not denigrating, remarks about Lysias: he is introduced as a

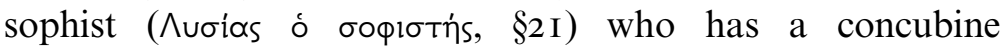
Metaneira (from the same background as Neaira), whom Lysias wanted to initiate into the Eleusinian mysteries. According to this speech, Lysias hosted both Metaneira and Neaira at his friend's place rather than in his home, because he did not want to embarrass his wife and family by the presence of the two concubines in his home. It is generally accepted that the mention of Lysias in this passage refers to the famous speechwriter Lysias, ${ }^{2}$ and this passage is usually included among sources for Lysias' biography. As already mentioned above, it is interesting that Lysias is called here a sophist with the assumption that it will be clear to everyone who was meant. The resonance of this word in this context is not entirely clear. Perhaps referring to Lysias as a speechwriter

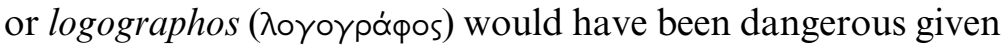
the fact that the very speech was written by Apollodorus and delivered jointly by his brother-in-law as the main accuser and

\footnotetext{
I I follow the text printed in Carey (I992). For a historical discussion of and commentary on the speech, see Wolpert and Kapparis (20II), I87-226.

${ }^{2}$ E.g. Dover (I968), 36-8.
} 
himself, ${ }^{3}$ and a reference to another speechwriter might have made the jury suspicious. On the other hand, Lysias could not have been called a rhetor ( $\rho \dot{\tau} \tau \omega \rho$ ) or orator either, because as far as we know he only delivered two speeches (if any) and could not participate in current politics. If we take Plato's Phaedrus at face value and Lysias did indeed engage in a variety of rhetorical activity (instruction of sorts together with speechwriting), it may make more sense to call him a sophist and also assume the audience's familiarity with him (cf. Phaedrus' perception of Lysias in Plato's dialogue).

It is noteworthy that the titles of speeches attributed to Lysias in antiquity mention many fifth- and fourth-century BCE intellectuals and public figures, thus suggesting that he was involved (or was perceived as someone who could have been involved) in writing speeches (either prosecution or defense speeches) for them. Among the list the most famous is probably Lysias' alleged defense speech for Socrates, ${ }^{4}$ which will be discussed in more depth below. But there are also speeches mentioning Xenophon (speech II7, fr 259), Demosthenes (speech 37, fr 79-84), Nicias (speech I I I, fr. 244), Isocrates (speech 75, fr. I78-9), Sophocles (speech I 25, fr 269), Aeschines the Socratic, ${ }^{5}$ and many more public figures of fourth-century BCE Athens. Many of these titles are very possibly suspect, but it is nevertheless curious that Lysias seems to have been associated with writing speeches either in favor of or against famous public figures. The speech allegedly written by Lysias against Demosthenes' guardianship (i.e. a prosecution speech of Demosthenes?) is a case in point: the

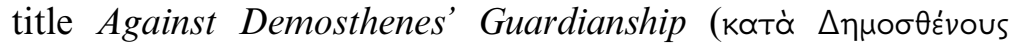

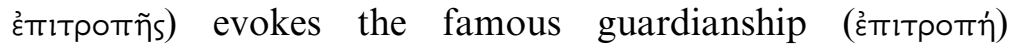
speeches of Demosthenes, which became fundamental for

${ }^{3}$ Carey (I992), I-2; Wolpert and Kapparis (20I I), I87-I88.

4 The notorious apology for Socrates is collected in Carey (2007) as speech I27, fragments 27Ia-6.

5 There is also one later source that comments on Lysias' enmity with Aeschines. Diogenes Laertius tells us in his treatment of Aeschines the Socratic that there was a confrontation between Lysias and Aeschines: Lysias had apparently written a speech called Пврі бuкофаvтís against Aeschines, who according to Diogenes imitated the style of Gorgias (DL 2.63). 
launching Demosthenes' political career. ${ }^{6}$ On chronological grounds of course Lysias' authorship of a speech relating to Demosthenes is impossible, since Lysias probably died around 38 о все (379/8 в Се according to Dionysius) and Demosthenes was born in $384 \mathrm{BCE}$. Yet, the fact that Lysias was perceived to have written a speech in relation to that particular, and rather personal, event in Demosthenes' life may tell us something about the image of Lysias as a speechwriter. ${ }^{7}$ Namely that Lysias was associated with cases that mixed the highly personal with the highly political (e.g. Demosthenes' first trial on his private matter about inheritance also launched his political career; Socrates' private trial also brought philosophy to court and immortalized the philosopher). In the case of Demosthenes' guardianship speech, since it could not have been written by Lysias for delivery in the actual trial, two solutions present themselves: either this fragment is a genuine speech by Demosthenes' opponents (or the speechwriter they hired) wrongly attributed to Lysias, or a rhetorical exercise from a later period depicting an encounter between Lysias and Demosthenes. In both cases, attaching the speech to the Lysianic corpus manifests the biographical interests of later scholarship in finding links between famous ancient personages about whom they no longer possessed affirmative biographical information. Be that as it may, the extant speeches, fragments and titles have shaped our perception of Lysias as an author: he is depicted as a speechwriter who is most closely associated with private and personal cases, and it is worthwhile to explore whether this association was already made in the earliest reception of his works.

If (as our sources suggest) Lysias' perceived talent in speechwriting did not lie in specialization in any particular kind of legal procedure or in any specific genre of rhetoric (forensic,

${ }^{6}$ Worthington (2013), 26. A good detailed overview of Demosthenes' guardianship speeches can be found in MacDowell (2009), 30-58.

7 I think that fr. 82 (Carey) of Lysias 37, a reference by Harpocration in which both Lysias' speech and another preserved speech by Demosthenes are mentioned side by side, might confirm that it was indeed the famous Demosthenes that was associated with Lysias' speech. 
epideictic, deliberative), it is probable that his reputation had something to do with his approach to certain themes or particular elements he used in composing his speeches. By merely looking at the corpus (including fragments), we will find little evidence to say anything more specific about this possibility. It is striking, however, that the Corpus, admittedly consisting of authentic and non-authentic speeches by 'Lysias', shows a great number of defense speeches, ${ }^{8}$ and this is a genre that Usher has found to give most room for character portrayals. ${ }^{9}$ Indeed, among Lysias' extant speeches, some of his most vivid and well-known characters are developed in defense speeches. ${ }^{\text {Io }}$ This attempt to deduce characterization as the prime characteristic of Lysias' speeches and the reason for his logographic fame is however based on a circular argument: from the content of the Corpus as we have it now suggestions are made about the particular abilities of 'Lysias', which are then taken to have preceded the Corpus and to have actually determined the focus of the existing corpus. Hence, while this discussion has not brought us closer to the early reception of, and reactions to, Lysias' career and writings, this closer scrutiny of the various items of the Lysianic corpus seems to confirm that at the later stages of his reception when his speeches were collected more systematically by scholars and editors in Alexandria and Rome, Lysias' fame does become associated with his success at characterization.

Valuable sources for the earliest reception of Lysias' career and work are Plato's dialogues, which, however, have their own particular focus and agenda and thus cannot be taken as genuine historical records of Lysias' contemporary reception. Yet, before turning to Plato's treatment of Lysias, I would like to briefly explore one of the most curious titles in the Lysianic

${ }^{8}$ Fragments of Lysias that seem to be defense cases are: speech I4 (?fr. 3I), 24 (fr. 54-5), 29 (fr. 65-7), 35 (fr. 75-7), 42 (fr. 98), 50 (fr. I06-7), 57 (fr. I I 7-19), 60 (fr. I2 I), 76 (fr. I 80-5), 77 (fr. I86), 80 (fr. I89-90), 9I (fr. 204), 94 (fr. 206-7), I08 (fr. 240), I I I (fr. 244), I I 5 (fr. 257), I I6 (fr. 258), I 24 (fr. 233), I 27 (fr. 27I-6), I 35 (fr. 286-7), I37 (fr. 294-6), I4I (fr. 303).

9 Usher (1965).

ro I am thinking here, for example, of Euphiletos from Lysias I and the invalid from Lysias 24 , but the list could easily be continued. 
corpus, The Apology for Socrates. This title stands out because it brings together two famous personages (Lysias and Socrates) around a watershed event of the early fourth century BCE, an event which shows Lysias at the beginning and Socrates at the end of his career. The Lysias-Socrates encounter, whether imagined or not, gives us an interesting insight into the development of Lysias' reception and all three versions of the story that circulated in antiquity are thus worth a closer look.

The story about the defense speech that Lysias had allegedly written and presented to Socrates is first attested in Cicero ( $D e$ oratore I.54, 23I) and is subsequently elaborated by other authors. ${ }^{\text {II }}$ It should be noted that the story and its (re)interpretations are primarily focused on Socrates' refusal of Lysias' defense speech on the grounds that it is not suitable for him. In all extant versions of the anecdote, this is clearly the main focus of interest. In Cicero's De oratore, Socrates is said to have read Lysias' speech not unwillingly (non invitus) and commended the speech as 'skillfully written' (commode scriptam esse), but rejected it eventually on the grounds that it was not manly (virilis) and stout (fortis) enough, just as he would not wear comfortable Sicyonian boots for the same reason. In other words, Lysias' speech was perceived by Socrates as not duly representing his character.

Diogenes Laertius' version of the story emphasizes the rejection of Lysias' speech by Socrates on similar grounds: Lysias'

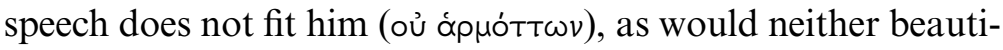

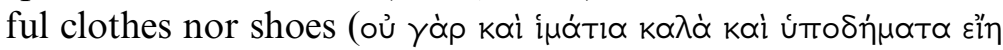

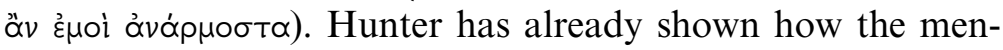
tion of clothes and garment can be seen as parallel to the rhetorical embellishments of Lysias' speech. ${ }^{\mathrm{I} 2}$ However, given that Lysias had been praised by Dionysius in the first century

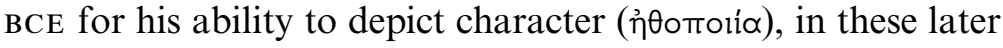
reworkings of this anecdote it must have been a deliberate

${ }^{I I}$ It is mentioned subsequently in Quintilian (Institutio 2.I5.3I, I I.I.I I), Valerius Maximus (6.4.ex2), [Plut.] ( $X$ orat. 836b), Diogenes Laertius (2.40), Stobaeus (3.7.56), and by the scholiasts of Aelius Aristides' Panathenaicus (as collected in Carey 2007). This discussion is heavily indebted to Hunter (20I2), chap. 3.

${ }^{12}$ Hunter (2OI2), IO9-I2. 
point, and somewhat of an embarrassment for Lysias, that Socrates rejects the speech because of Lysias' failure to depict a fitting character. There must have been calculated irony in sharing or transmitting these anecdotes about Socrates/Lysias while at the same time recommending Lysias as a model for characterization. As Cicero's passage suggests, had Socrates accepted Lysias' speech, he would not have lost the trial, for the speech, which probably showed Lysias at its best, was perfectly fitted to the expectations of the courtroom. ${ }^{\text {I3 }}$ Socrates rejected, then, not only the rhetoric of the courtroom, but precisely this kind of rhetoric that operates with character manipulation which Lysias was so famous for.

The connection between rhetoric and character in Lysias' speech is expressed even more strongly in the version of Valerius Maximus, where the story is narrated to exemplify the importance of gravitas among illustrious men, who have preferred death over life without gravitas. ${ }^{\mathrm{I}}{ }^{4}$ The lack of gravitas appears to be also the criticism of Lysias' speech by Socrates, who after hearing Lysias responded by saying that nam ego, si adduci possem ut eam in ultima Scythiae solitudine perorarem, tum me ipse morte multandum concederem ('If I could be persuaded to deliver it in the farthest wilderness of Scythia, I should admit myself that I deserved death'). Moreover, Valerius Maximus concludes that spiritum contempsit ne careret gravitate, maluitque Socrates exstingui quam Lysias superesse ('he despised life lest it be without gravity and preferred extinction as Socrates to survival as Lysias'). ${ }^{\text {I5 }}$ The claim here is that accepting Lysias' speech would commit Socrates to the kind of personality and character that is depicted in that kind of speech. This, however, is regarded to be in contrast with everything that Socrates came to represent, so that he would at any moment choose death over such a life. In sum, whatever the individual nuances of these different

\footnotetext{
13 This is precisely Quintilian's point in the two passages where he discusses the anecdote.

${ }^{14}$ Valerius Maximus 6.4.ext.2.

I5 I follow here Shackleton Bailey's (2000) edition and translation.
} 
interpretations of the anecdote, all these stories make a clear association between Lysias' skill and success as a speechwriter with a particular talent for creating persuasive characters, and Socrates' refusal to profit from this skill, as it would not portray his character truthfully. This sheds some light on the perception of Lysias 'the author' in the later stages of his reception, and as will be discussed below, will find support in the way in which 'the Lysianic' is understood in Plato's Phaedrus.

\section{I Plato's Lysias}

Plato is the first critic of Lysias and his Phaedrus is before Dionysius of Halicarnassus the most valuable engagement with, and record of, Lysias as a writer and intellectual. In the following pages, we will explore the extent to which our current, and presumably also the ancient, reception of Lysias is directly indebted to Plato's dialogues, and what that means for Lysias' Nachleben and the rhetorical tradition more generally.

The suggestion that Plato is directly related to the reception of Lysias might sound at first instance surprising. Sure, they are both interested in rhetoric, but from completely different angles and with different aims. What links the two? On the one hand, their intellectual environment: they both move in (the same) high circles of Athenian elite and thus share a similar background. On the other, literary and possibly also political feud: the praise of Lysias as the most accomplished contemporary writer followed by heavy critique indicates, among other things, a sense of rivalry between the writers. Politically speaking, Lysias' speech I2 associates him strongly with prodemocratic sentiments and tries to play down his own elite status as much as possible (by emphasizing instead the struggles of the metic community). Plato's references to Lysias consistently associate him with the political and intellectual circle that is cohabited by Plato: the anti-democratic elite. In the end, Lysias' character seems to serve for Plato two different, but interconnected, functions. As a generic character he stands for speechwriters and pseudo-intellectuals (or rather, 
anti-intellectuals) in Athens more generally. This way Lysias becomes the representative of a kind of rhetoric that Plato finds particularly difficult and reprehensible. As a particular character, Plato is using Lysias to map out the field of rhetoric through its practitioners and their interrelationships in contemporary Athens.

Lysias is mentioned several times in Plato's dialogues. The most extensive focus on Lysias is in the Phaedrus, but before embarking on a closer analysis of the representation of Lysias in this dialogue, let us briefly take a look at other dialogues which feature, in a more or less significant way, Lysias. Aside from the Phaedrus, Lysias is mentioned in two other dialogues: three times in the either spurious, dubious or incomplete dialogue Cleitophon, twice in the opening section (406a2, 406a6) and once in the concluding passage (4IOe4), and once at the beginning of the Republic (328b4).

Cleitophon, which appears to present an explicit attack on Socrates and his philosophical method, is a puzzling dialogue. The authenticity of the dialogue was not questioned in antiquity, ${ }^{\text {I6 }}$ though scholarship from the nineteenth century onwards has been very critical of the dialogue and suspicious of its authenticity. The most important issue for scholarship has been the content of the dialogue and the fact that it lacks Socrates' response at the end, which would address the accusations made by Cleitophon. ${ }^{17}$ However, a closer look at the dialogue reveals that it has a coherent and finished structure, thus casting doubts on the notion that the dialogue was left unfinished and/or abandoned. ${ }^{18}$ Furthermore, Slings argues that the Cleitophon belongs to a separate dialogue genre that

${ }^{16}$ Slings (I999), I I traces back the hypothesis that the dialogue is not authentic to Ficino.

${ }^{17}$ For a more thorough discussion of all possible pro and contra arguments on the question of authenticity, see Slings (I999), 227-34. Slings notes (I2) that the suggestions of the nineteenth-century scholars were 'connected with the supposition that the Cleitophon was originally intended as a prooemium to the Republic', but that Plato had apparently changed his mind halfway through and made use either of the alleged dialogue Thrasymachus or of the Euthydemus instead.

${ }^{18}$ Rowe (2000), 303-7 notes, for example, that the Cleitophon reads like a commentary on the Republic and might have been an attempt of the older Academy to critically engage with Plato's political thought. 
he calls the 'short dialogue'. ${ }^{9}$ Most of Plato's shorter dialogues are included in this category (many of which have also been considered spurious), and it has its own characteristic features with which the Cleitophon seems to conform. ${ }^{20}$ For the purposes of the current discussion, it is not totally irrelevant whether Plato was the author of the dialogue, especially if there is a sense of a rivalry between Plato and Lysias, literary and/or political, that emerges from looking at the way Plato portrays Lysias in his work. Having said that, however, my reading of the relevance of Lysias in the dialogue is not overly dependent on the authorship of Plato; as long as the dialogue can be safely placed in the context of the Academy (and the fourth century BCE), something that has not really been doubted in scholarship thus far, my argument could be read independently from disputes about the authenticity of the Cleitophon.

One of the most important characteristics of short dialogues is that they go straight to the core of the problem that forms the central discussion in the dialogue, thus making every little detail and character mentioned even more relevant to the underlying issue. From this perspective, then, the fact that Plato introduced a conversation with Lysias as the starting point for the discussion in the short Cleitophon is significant. In fact, Lysias features (or is mentioned in passing) at the beginning of three of Plato's dialogues (Phaedrus, Republic, Cleitophon) and disappears from the body of the work (except for the Phaedrus where Lysias is mentioned again at the end of the dialogue). ${ }^{2 \mathrm{I}}$ Let us take a closer look at the Cleitophon to

19 Slings takes his cue from Müller (I975), even though there is a significant difference between Slings and Müller: when Müller introduced and discussed the term 'short dialogue' (Kurzdialog) he argued that they ought to be rejected on the whole as not genuinely Platonic. Slings uses the term and agrees with the generic category of 'short dialogue', but does not follow Müller's position about the unauthenticity of the genre.

${ }^{20}$ E.g. Slings discusses length, lack of individual characterization, lack of pedimental structure, etc.

2 I An excellent discussion of the role of 'first words' in interpreting Plato's dialogues is Burnyeat (I998). 
see what kind of role Lysias might have on setting up the framework and central question of the dialogue.

Mentioning Lysias at the beginning of the dialogue seems to suggest some kind of engagement with rhetoric, speechwriting or an intellectual environment where these two are discussed and/or practised. ${ }^{22}$ Slings goes further and points out that the dialogue has a clear structure that seems in line with the conventions of courtroom speeches. ${ }^{23}$ Indeed, the dialogue is essentially a long speech, incorporating dialogical (or pseudodialogical) elements, about Socrates' virtues and shortcomings as a teacher. It is certainly relevant that the discussion that Cleitophon had with Lysias concerned Socratic teaching in particular and did not appear to have reflected on education in a more abstract sense (e.g. trying to answer questions such as 'whether virtue is teachable?'). The object of criticism is not, therefore, philosophy and its usefulness, but rather Socrates' teaching methodology - how to best educate and bring pupils to one's preferred subject. We see here, then, how Lysias - in conversation with Cleitophon - has prompted a fundamental critique of Socratic teaching, clearly questioning Socrates' protreptic method and its ability to do real philosophy. Socrates is regarded as an inspiration in the beginning, but afterwards as an obstacle to his students' pursuit of philosophy. I believe that this is not a trivial question - Socrates' character and his teaching methods seem to have been hotly debated in antiquity as they are today. ${ }^{24}$ The Cleitophon,

22 According to Geffcken (I933), this dialogue is essentially a rhetorical speech. Geffcken argues, pace Friedrich Schleiermacher (I836, 347-9), that it was not written by Plato but is the work of the fourth-century rhetorician and dramatist Theodectes who reacted with this piece against the Platonic Socrates (and not against Socrates himself). Orwin (I987) advances an interesting view of the Cleitophon as a response to Socrates' speeches in the Apology, arguing that in this dialogue Cleitophon proposes a defense speech against the accusations of Socrates to justify (the conduct of) Athens. Some of Orwin's conclusions are similar to those advanced in this chapter, especially when he proposes (I29) a third possibility for interpreting Socrates' ambiguity with regard to the question of 'justice': Socrates is willing to say what justice is but unable to say it to Cleitophon.

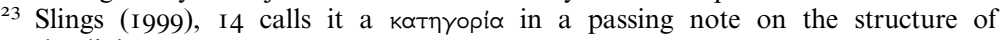
the dialogue.

${ }^{24}$ The importance of Plato's character-creation is effectively pointed out in Press (I993b). 
therefore, whether or not an authentic work by Plato, evokes a very crucial concern about the Platonic dialogues and Socratic teaching methodology in particular. In this sense, it is not unimportant that it was precisely Lysias who seems to have brought up the question about Socrates' teaching in the first place.

There are two further points that I would like to briefly mention in relation to the Cleitophon: first, our knowledge of Cleitophon and his association with Lysias, and second, the interpretation of Socrates' silence at the end of the dialogue and how this might feed into the general picture of Lysias in Plato. To start with the second point, the fact that Cleitophon casts a rather unexpected and perhaps embarrassing light on Socrates' philosophical activities seems to be agreed on by most commentators. ${ }^{25}$ If Socrates' silence at the end of the dialogue is taken as an acknowledgement or confirmation of a problem in Socratic teaching, the Cleitophon depicts a problematic defeat of Socrates by an eloquent interlocutor and the dialogue could be compared in this respect with some passages of the Euthydemus or the Gorgias. What strikes us about these comparisons is that in those dialogues (i.e. in Euthydemus and Gorgias) Socrates puts forward explicit criticisms of his interlocutors throughout the work and we are invited to take the side of Socrates who, even if ridiculed within the dramatic context of the dialogue, still has the upper hand in the overall argumentative structure of the dialogue. In Cleitophon, however, Socrates' explicit criticism of, and response to, his opponents is absent. To answer the second question, then, the dialogue certainly evokes crucial questions about Socratic method and Lysias is clearly associated with Athenian intellectuals who are overtly critical of Socrates.

The first point about Cleitophon and his character might help shed further light on the question. From the way Cleitophon is

${ }^{25}$ Schleiermacher (I836), 347 argues that it cannot be a Platonic dialogue precisely because of this embarrassing conclusion; Slings (I999), I 8 claims that Socrates 'has been beaten at his own game'. Rowe (2000) proposes a convincing reading of the Cleitophon as seriously challenging the philosophical method presented in the Republic. 
characterized in the dialogue, we understand that this is a man who is impatient to find out the right answers and, hoping to reach a state of clear knowledge, frequents several different philosophical schools and listens to many different philosophers who teach - we are led to assume - different things. Indeed, Cleitophon describes himself at the end of the dialogue as

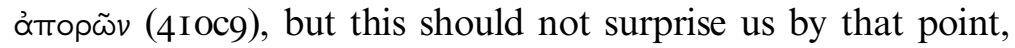
not after we have followed his restless and eclectic switching between philosophical schools and arguments. In a sense, as much as the dialogue appears on the surface to focus on Socrates' confusing protreptics, it actually gives the reader a close-up of an individual (Cleitophon) who is so enthused by and imbued in protreptic writings that he is unable to recognize philosophical thinking proper when he is confronted with it (e.g. in the Republic where he is unable to follow the discussion). ${ }^{26}$ Plato's Socrates remains silent at the end of the dialogue, according to this reading, because Cleitophon's criticisms grossly misrepresent Socrates' philosophical method to the extent that they have simply no shared ground upon which to build a constructive discussion. What should Socrates possibly reply to Cleitophon's claims of having been an ardent 'fan' of Socrates who he thought produced (praise?) songs (ú $\mu v \varepsilon \tilde{v})$ just

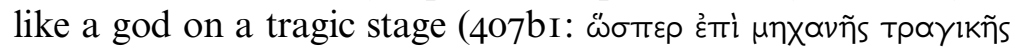
$\theta \varepsilon o ́ s) ?^{27}$ Most importantly, Cleitophon has no patience for this

${ }^{26}$ I hope to demonstrate this reading, and Plato's criticisms of the protreptic genre, in a forthcoming article on Plato's protreptics in more depth.

27 I follow Slings' text, which has úuvoĩs (as an optative in distributive temporal clause)

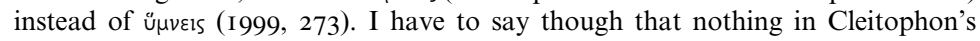
portrayal of Socrates makes much sense. If he is indeed referring, as Slings suggests, to the famous scene in Aristophanes' Clouds (vv. 2I 8-2I), 'where Socrates "enters" the stage in a basket hanging on a $\mu \eta \chi \alpha \nu \eta$ and behaves (and is treated) like a deity', why mention the tragic stage? Slings suggests that Cleitophon might be referring to Socrates' speeches as too lengthy, but this does not square well with the comparison to the tragic god, for it is not necessarily obvious that gods in tragedy are perceived as embarking on extended expositions. In fact, the tragic context might suggest an interpretation of a Socrates who instead of allowing discussion to follow its natural course emerges as if out of nowhere, stops serious (philosophical) contemplation and gives orders about how to go about solving the situation and, implicitly, about how to live one's life. Yet, by the end of the dialogue we realize that this is exactly what Cleitophon is longing for - clear answers and concrete practical advice that Socrates, according to him, is unable to offer. In whatever way we try to make sense of this, then, Cleitophon's comparison is confusing in the extreme. Useful 
kind of Socratic teaching: he makes use of the Socratic question-answer method, thus showing himself to be superficially aware of it, but he uses this not for the purposes of exploring the truth together with his interlocutors (and hence becoming more knowledgeable together with them), but rather to challenge them impatiently when they fail to give him a satisfactory definition. ${ }^{28}$ When summarizing Socrates' views on justice (4IOa8-b2), Cleitophon dismisses him as merely contradicting himself or being, at best, ambiguous and undecided. This is a clear reference to Republic I, but Cleitophon's conclusion hardly represents what Socrates has to say about justice in this dialogue. We should note that the Republic is the only other dialogue by Plato where both Cleitophon and Lysias are mentioned as participating, even if not contributing (and this is important!), to the philosophical discussion. ${ }^{29}$ Lysias is a silent listener in the Republic (never directly exposed to a Socratic inquiry), but vocal among his associates about the shortcomings of Socrates' views. There is a sense of insincerity in both Lysias' and Cleitophon's behavior that is directly alluded to in the beginning of the dialogue by Socrates' direct confrontation with Cleitophon. Even though present, they expressed their criticisms of Socrates' views behind his back without aiming to engage in a serious and open discussion of the topic. And looking at what else we know of Cleitophon, this is very suggestive. Apparently Cleitophon was a well-known figure in Athens, particularly

comments on the staging of the Aristophanic scene are in Dover (I968a), I24-7 (at vv. 2I3-26).

${ }^{28}$ This is not to deny that Cleitophon's challenge about the (non)approachability of Socratic teaching might also be a genuine one. This is what Slings (I999) has in mind when he argues that Cleitophon is 'obviously the hero, not the villain, of the dialogue', and that the aim of the Cleitophon is 'to deride protreptic Socratic literature, not to suggest that the statements found in that literature are nonsense' (49).

29 Republic I 328b. Cleitophon tries to contribute to the discussion at $340 \mathrm{a}-\mathrm{b}$, but seems not to have understood the arguments and his suggestion is rejected immediately. This passage suggests rather unequivocally that Cleitophon is not depicted particularly charitably in Republic I, and it is unclear why Slings pushes for reading the character in a favorable light (or like a potential victim of bad influences, 55-6) both in the Republic I and in the Cleitophon. 
notorious for his 'flip-flopping political attitudes' ${ }^{30}$ He seems to have had consistently oligarchic views and paved the way towards the oligarchy of the Four Hundred in $4 \mathrm{II} .^{3 \mathrm{I}}$ Associating Lysias, the staunch proponent of democracy (or so it appears from his speech I2), with Cleitophon could be potentially damaging to both, but perhaps especially to Lysias, one of the richest metics in Athens who seems to have gone through a great deal to present himself as suffering along with the demos in the oligarchic coups. Plato took meticulous care in crafting the characters of his dialogues and we can therefore assume that none of the people mentioned in his works are there by accident. ${ }^{32}$ So too for Cleitophon: it is certainly not accidental that Lysias' name is dropped at the beginning of the Cleitophon and that it was a conversation between Cleitophon and Lysias that triggers this dialogue. This may seem a very subtle reading of the short dialogue for modern readers, but for the immediate audience of the dialogue it may have suggested more readily that Plato's choice to bring together these two characters would cast problematic light on both Lysias' political as well as intellectual allies.

Another scene portraying Lysias together with an admirer and potential student is referred to at the beginning of the Phaedrus. There, the whole discussion about rhetoric is prompted by Phaedrus' admiration for the speeches of Lysias

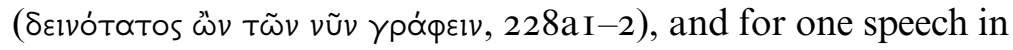
particular that he had heard delivered in Epicrates' house. Phaedrus says that he had been sitting the whole morning indoors with Lysias and needs to take a walk outside the city to freshen up (227a2-5). Whoever else was present in Epicrates' house with Phaedrus and Lysias we do not know, but the lack of references to a larger group suggests that we may plausibly suppose their encounter to have been a kind of 'private lesson' by Lysias. Phaedrus' learning process is laid out in hypothetical terms by Socrates in $228 \mathrm{a}-\mathrm{b}$ and is subsequently confirmed by

$3^{30}$ Nails (2002), I02. $\quad{ }^{31}$ See Ostwald (1986), 475 and 478.

${ }^{32}$ A great discussion of the multilayeredness of Plato's characterization is Blondell (2002), esp. chaps. I and 2. 
Phaedrus: he had indeed received instruction from Lysias and had hoped to use Socrates to rehearse Lysias' speech (228c6-7, $228 \mathrm{~d}_{\mathrm{I}}-4,228 \mathrm{e} 4-6$ ). Lysias is never portrayed as eloquent with the crowds in Plato (perhaps due to his metic status), but is frequently referred to in a one-to-one instruction setting (cf. Cleitophon and he never says a word in the Republic). As such, he stands in contrast to Socrates, who is often portrayed by Plato in conversation with a larger group of Athenians. The Phaedrus is in this sense a fascinating exception, especially given its focus on rhetoric, a topic that is tackled in the Gorgias in front of a large and contentious crowd. Socrates' quest for knowledge is transparent and open for everybody to join, whereas Lysias' skill will be learned and transmitted behind closed doors. It is a paradox indeed that despite all the prodemocratic rhetoric in speech I2, Plato chooses to characterize Lysias as an elite writer and instructor, inaccessible to the demos and uncomfortable in the public spotlight. ${ }^{33}$

The association of Lysias with Epicrates is a case in point. Much like Cleitophon, Epicrates was a rather controversial figure, well known for his wealth and influence, but notorious for questionable political behavior. Epicrates fought in 403 on the side of democracy (Demosthenes I9.277), like Lysias, but was later associated with corruption and taking bribes. ${ }^{34} \mathrm{In}$ fact, alongside other sources, a speech by Lysias reveals that a certain Epicrates had a history of giving bribes (Against Epicrates 27.I-9). If this is indeed the same Epicrates mentioned in the beginning of the Phaedrus as Lysias' host, ${ }^{35}$ then the (later) reader of the Platonic dialogue might be surprised to find the two depicted as associates. ${ }^{36}$ The image is made

${ }^{33}$ It is perhaps worth reiterating that this suggestion only applies to the image of Lysias created in Plato's dialogues and has no ambition to say anything about the historical Lysias, his political orientation, friends or rhetorical teaching practices.

34 Nails (2002), I39. Pausanias 3.9.8, for example, associates Epicrates with taking bribes from Persians and stirring up war in Greece against Spartans.

35 As suggested by Nails (2002), I40. It is interesting that this appears to be the same Epicrates we encounter as the addressee of Demosthenes' Erotikos (more on this below).

${ }^{36}$ It is interesting too that Lysias associates Epicrates' wealth with war (27.I0), suggesting that the latter has made a large fortune during war time, at the expense (we might think) of other people's suffering. 
worse by mentioning Morychus, a well-known personage who was mocked in comedy for his gluttony and high living. ${ }^{37}$ The environment where Lysias stayed while in Athens was one dominated by wealth, abuse of power and political influence. In sum, we see in this first scene of the Phaedrus that Lysias is associated with morally (if not politically) dubious characters and this characterization offers another dimension to the introductory part of the dialogue, and one that challenges the overt praise with which Lysias is brought to the conversa-

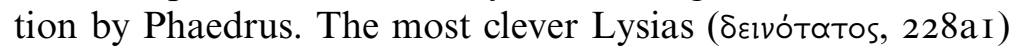
might acquire here another dimension: the clever and dangerous. ${ }^{38}$

But what exactly was Lysias doing in Epicrates' house? Phaedrus says that he 'spent a long time there [with Lysias],

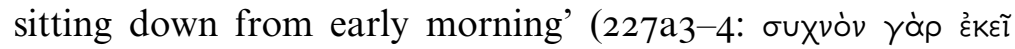

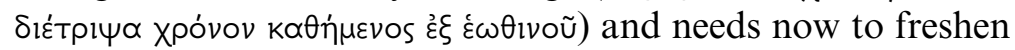
up. This description seems to suggest a longer exchange than simply attending a speech performance. Also, it seems that Phaedrus made up the whole audience. Socrates seems to suggest that Lysias offered some sort of exegetical practice after having delivered the speech. The word Socrates uses

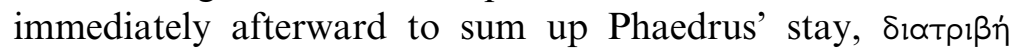
(227b6), is ambiguous and could suggest either a study or simply 'time spent'. In fact, Socrates himself finds it relevant to inquire what kind of gathering it was, only to reply to his own question immediately with a suggestion that it must have been 'a feast of speeches that Lysias offered' (227b6-7: भै $\delta \tilde{\eta} \lambda \circ v$

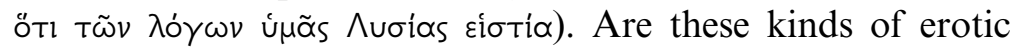
display speeches the kind that Lysias was in the habit of composing and sharing with his admirers? Let us bear in mind the fact that the dramatic date of the dialogue suggests a time well before the oligarchic coup and thus the eventual start of Lysias' speechwriting career. By the time the Phaedrus is

37 Nails (2002), 208; Yunis (20II), 86. See comic references to Morychos in Aristophanes Acharnians 887, Peace I008-9, Wasps 506.

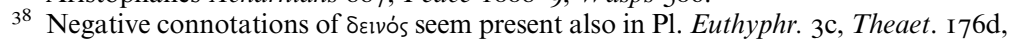
Euthyd. 304d. 
composed, the reader would of course associate Lysias with his courtroom speeches and so an interesting anticlimax is built up at the beginning of the dialogue, where Phaedrus exposes the topic of Lysias' speech: not at all a court speech for a famous personage or witty portrayal of an Athenian litigant, but rather a sophistic argument to win over a lover! In the very beginning of the dialogue, in other words, Plato turns the image of Lysias upside-down: we are not confronted with a staunch democrat and a courtroom speechwriter, but instead with an elitist intellectual who spends time with wealthy and morally questionable characters, producing and performing discourses that appear to have very little serious content to them. ${ }^{39}$

It is important to draw out another, arguably the most important, line of argument in Plato's portrayal of Lysias Lysias as an incapable practitioner of his own art. As we saw, the Cleitophon and the Republic depict Lysias as the silent character in group discussions who is not interested in philosophy (Republic), even though he seems eager to criticize in private the methods of the kind of philosophical examination conducted by Socrates (Cleitophon). The Phaedrus goes further and later on in the dialogue suggests more explicitly that Lysias does not have the mind for philosophy $(279 a 3-b 2) .^{40}$

39 It is of course conceivable that the historical Lysias was engaged in a range of activities, including erotic epideixeis, and that we should not regard Plato's focus of attention as subversive or ironical any more than it is simply emphasizing one aspect of Lysias' professional career. But it nevertheless remains curious that of all the different rhetorical contexts that Lysias might have been engaged with, Plato chose to emphasize this one: Lysias as an elitist speechwriter and rhetoricianentertainer (rather than, say, populist democrat). Furthermore, Plato's portrayal also entails explicitly contradictory elements about Lysias' life, namely the fact that he started his writing and/or teaching career well before 403 (as usually listed in his biography) and the political undertones of such portrayal seem explicit enough to suggest a more critical commentary from Plato.

40 Though in $257 \mathrm{~b}$ Socrates seems to entertain the possibility that Lysias could be turned to philosophy. J. Howland (2004) argues that reading the Phaedrus and the Republic together as commenting on the passionate and erotic nature of philosophy, the former dialogue also portrays 'Lysias as unerotic and therefore unphilosophical' (I8I). Howland then makes a bolder, and in many ways a rather implausible, claim by suggesting that Plato's Republic is on one level 'meant to be a Platonic response to [Lysias'] Against Eratosthenes'. There are many problems with his argumentation, and perhaps the most obvious one is Howland's lack of attention to the differences in genre and context of works such as Lysias' Against Eratosthenes and Plato's Republic. 
While Isocrates will grow out of his present activity (preoccu-

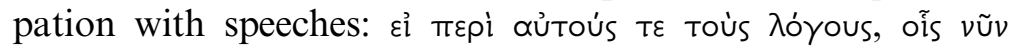

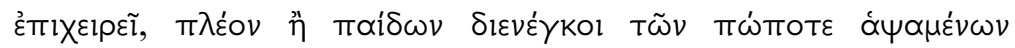
$\lambda o ́ \gamma \omega v, 279 a 5-6)$ and ascend to follow his more divine philosophical nature, as Socrates predicts, Lysias remains where he is, writing speeches as he has always done. ${ }^{4 \mathrm{I}}$ We will take a closer look below at the role and portrayal of Isocrates in this dialogue. For the time being, suffice it to say that there are good reasons for taking the comparison sketched out in this passage at face value and positioning Isocrates far higher in Plato's (or Socrates') overall estimation of contemporary rivals/teachers than has been hitherto considered.

Importantly, Lysias' proclaimed inability does not only affect Lysias' philosophical prospects. Socrates' analysis and judgement of Lysias' composition earlier in the dialogue pointed out that the latter has performed below the standards of his own (rhetorical) art. According to Socrates, Lysias' speech was unnecessarily repetitive, failed to bring out a diverse set of compelling arguments in favor of the main point (235a3-6), and badly organized (e.g. the Midas epitaph in 264d). He grants Lysias his eloquent style ('expressions are clear and well-rounded and finely turned', 234e5-6), but claims that he could easily come up, on the spot, with an equally good (or even better) speech as that of Lysias $(235 \mathrm{c} 4-5) .{ }^{42}$ The much-praised composition of Lysias that so delighted Phaedrus turns out to be an average example of the art at best. Lysias' speech will be scrutinized also at a later stage in the dialogue: from $262 \mathrm{c} 4$ onwards Socrates analyzes the beginning of Lysias' speech and finds it lacking of the kind of structure

${ }^{4}$ Lysias is also (negatively) compared in another passage of the Phaedrus to his brother Polemarchus (257b) who has turned towards philosophy, whereas Lysias has not.

42 Perhaps this is one of the reasons why Lysias' oratory is relatively easy to imitate, or - to put it differently - why it is possible for Plato to produce a 'Lysianic' speech: there is no 'deeper level' of meaning in Lysias' work that one might miss and hence misrepresent in an imitation of his writing; as Phaedrus seems to suggest, it is sufficient to come up with an unexpected twist to the topic to make a discourse seem Lysianic. 
that he and Phaedrus had previously agreed should be exhibited in a successful composition. Throughout the dialogue, then, Lysias is constantly exposed as underperforming in an art that he is so famous for.

This tells us, of course, something about philosophy and something about rhetoric. Perhaps most obviously, by pointing to the impact of Lysias' speech on both Phaedrus and Socrates, the dialogue indicates the power of rhetoric to force the listener to forget oneself and immerse oneself in the story. ${ }^{43}$ And it also suggests, through Socrates' clear-headed analysis of Lysias' speech, that philosophical training might be a good way to resist the temptation and illogical persuasion brought about by rhetoric. That much seems obvious. There remains the question about what this means eventually to Lysias, to his reputation and to his students. I propose that Plato's discussion of Lysias has two dimensions: the general and the particular. On a general level, Plato's Phaedrus marks the beginning of sustained attempts by philosophers to systematize the field of rhetoric. By weaving into his narrative a dizzying number of references to various contemporary and ancient orators and rhetoricians Plato not only demonstrates his competence in the field, but also offers a categorization of the different contributions rhetoricians have made and how to assess those. In the midst of the crowd of rhetoricians Plato singles out Lysias and Isocrates, thus creating through them an image of rhetoric as divisible into two larger categories. On a particular or individual level, Plato's portrayal of Lysias comes to dominate the reception of Lysias and his writing. As a metic who had few (if any) opportunities for public appearance, and thus to leave a record of his persona in history other than through his own works, Plato's scathing analysis of the incompetence of Lysias was going to leave a hostile trace in the reception history of this writer. The fact that posterity was

43 The idea of forgetting and knowing oneself is central to the crucial distinctions made in the dialogue between philosophy and rhetoric, between knowledge and appearance. On self-knowledge as the unifying theme of the dialogue, see Griswold (I986). 
not always very attentive to Plato's sarcasm and seems to have missed that point on occasion (though not, as will be argued below, in the case of Dionysius of Halicarnassus), is another story. It is also relevant to note that Plato's Phaedrus effectively gives us the only other speech by Lysias where the latter is portrayed as speaking in his own voice, therefore offering a competing account to Lysias' speech I 2.

It is clear, then, that Plato wrote the Phaedrus with a message about rhetoric in mind: the outlines of the art of persuasion, in all its messy contemporary context, are effectively drawn by two characters who offer contrasting visions for the art - Lysias and Isocrates. ${ }^{44}$ Indeed, the dialogue concludes with the request to report the outcome of Socrates' conversation with Phaedrus to Lysias and Isocrates, as figures of particular importance to the field of rhetoric. ${ }^{45}$ The two are pitched against each other

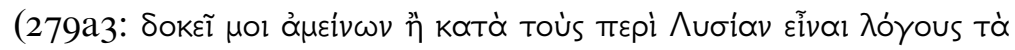

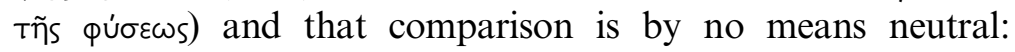
Isocrates comes out from this juxtaposition as a stronger and worthier representative of rhetoric.

We might indeed ask whether Plato was in fact fair in his assessment of Lysias' speech. Socrates appears naïve and/or insensitive to quite a few important aspects of Lysias' speech, in particular to the possibility that some of what he and Phaedrus have recognized as faults might instead have a specific (and well-calculated) function in the context of the speech. ${ }^{46}$ For example, the lack of clear definition of love at the beginning of the speech, a fault that brings Lysias' speech under renewed criticism (from $262 \mathrm{c} 4$ onwards), contributes to deliberately keeping the ambivalence about the topic and is therefore an important part of Lysias' argumentative strategy in the speech. ${ }^{47}$ Phaedrus himself showed where he thought the

\footnotetext{
44 This is not to make a claim about the main theme of the dialogue, which has vexed scholars since antiquity. Hermias' commentary on the Phaedrus (8.I 5-I2.25) from the fifth century CE seems to have been the first one expressing the problem of unity.

45 It is worth emphasizing that Plato does not claim to create a concept or discipline himself (e.g. as proposed by Schiappa I990 about coining the word rhetorike), but rather aims to shape and fix the outlines of an already existing practice of rhetoric.

${ }^{46}$ Ferrari (I987), 45-59. ${ }^{47}$ Ferrari (I987), 50-2.
} 
real contribution of Lysias' speech lies when he identified the particular twist to a commonplace topic as the very standout aspect of the speech (227c5-8). In other words, Lysias had set out to have a different agenda and strategy in composing the speech, so that Socrates' criticisms that are founded on strong commitments to philosophy and truth might strike the reader as insensitive or simply wrong when applied to Lysias. As Ferrari points out, Plato/Socrates' criticisms of Lysias run much deeper and eventually work towards a 'whole-hearted rejection of Lysias' way of life'. ${ }^{8}$

Based on what has been said thus far, it does seem that Lysias is represented in Plato's dialogues as a rather particular kind of intellectual, one that is often present in crucial contemporary philosophical debates, but never really allows his views to be directly exposed, tested or challenged. This Platonic Lysias is a representative of a kind of rhetorical practice that aims to impress with persuasive tricks and amusing twists and deliberately shuns pursuing truth and knowledge in their own right. From Phaedrus' adoring reaction we surmise that a writer like Lysias, whose plain style was appealing to the crowds but morally suspect, might have been an even more dangerous adversary to Plato's philosophical project than many (or even most) of his rivals (Isocrates, Antisthenes, or sophists who would follow the path of Gorgias, Protagoras or Euthydemus) who may have been willing to engage with Socrates' questioning of their activity. This is because Lysias' style is alluring, simple and effective in bringing about persuasion (Phaedrus is presented as a test case of the appeal of Lysianic rhetoric), but his content is driving the audience further from philosophy and, eventually, from themselves.

Plato exercised a significant impact on the reception of Lysias and his writing skills more generally. While his portrayal of Lysias as an 'anti-intellectualist' might have been his own inventive take on Lysias and one that was perhaps not 
that obvious to subsequent readers of the dialogue, the carefully constructed Lysianic speech of the dialogue reflects some of the most distinctive stylistic elements of Lysias' writing that have remained steadily fixed in the later perception of the writer. In particular, his Phaedrus seems to corroborate the general view of Lysias as the master of character delineation that was suggested above in analyzing other contemporary and later sources. Comparing all three speeches of the Phaedrus, we find the first, purportedly by Lysias, to stand out from the others by the number of references to characters and characterization in the speech. It is a paradox and at the same time a testament to the Lysianic writerly skill (albeit filtered through Plato) that this is perhaps also the only speech of the three that can actually be understood and delivered outside of its original context. The language of 'Lysias' is dominated by direct references to the speaker and the listener of the speech, ${ }^{49}$ clearly distinguishing the two roles in a way that we do not find in the other two discourses. The one, listener, is passively presented with the evidence and is expected to reach a decision by the end of the speech whereas the speaker is persuading the other to vote in his favor. By contrast, in his first ('Lysianic') speech Socrates, after invoking the Muses, ${ }^{50}$ begins with a mythical and a more general account of the situation at hand (237b3: $\tilde{\eta} v$

49 'Lysias" speech appears to have a structure of interchanging arguments based on a general-specific distinction. The speech begins with specific references to the

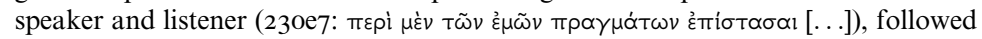
by a brief generalization of the lovers/non-lovers, then turning again to the actual

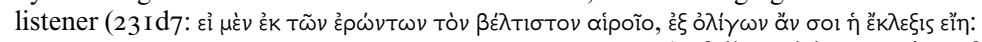

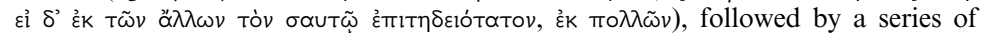

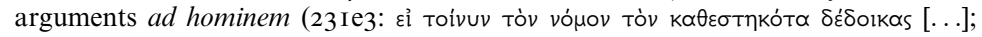

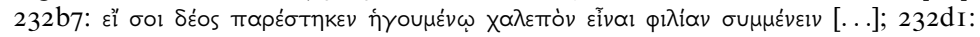

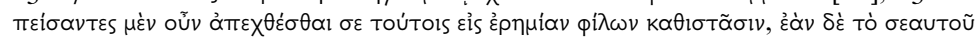

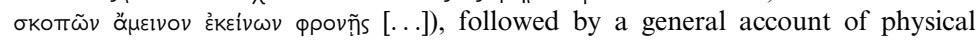
passion which is once again picked up by direct references to the speaker/listener

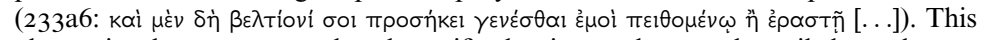
alternation between general and specific dominates the speech until the end, concluding with a very direct personal appeal and request to ask further questions.

5o This in itself is a very significant break from the previous speech by 'Lysias': there the excellence of the composition could not be attributed to anyone other than the excellence of the writer. 


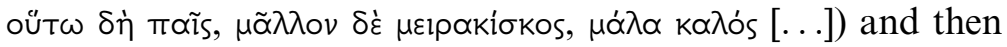
embarks on looking for a (abstract) definition of love (237c9dI). Contrary to that of 'Lysias', this speech is structured in such a way that one would see no reason to emphasize characters or to draw attention to the speaker and the listener as representing different sides of the discussion (e.g. a young desired boy at the receiving end of the speech versus the older man overcome by desire for the boy). Indeed, in this speech both are included in the narrative as if representing the same position of someone who is exploring the question of love. They are depicted as pursuing the argument together. This difference is crucial and becomes even more poignant with the conclusion of the speech, where the argument is developed into its most sinister results and reaches its climax in the horrific claim that 'just as the wolf loves the lamb, so the lover

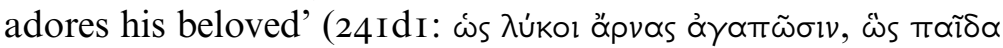

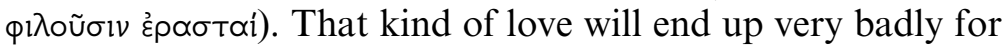
the beloved (he will be eaten and dead) and probably no

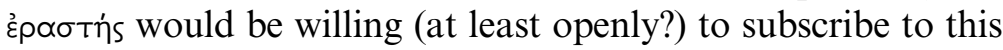
view. Thus, contrary to the first Lysianic speech, we are led to assume that the speaker of the second speech can by no means

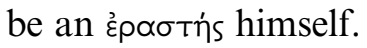

Not only is Socrates' argumentation in his first speech more abstract and general, ${ }^{5 \mathrm{I}}$ his speech is also much more serious than the first speech by 'Lysias'. In fact, part of the attraction of 'Lysias' speech is the relative ease with which one can see that the speech is not meant to be taken seriously, and that the speaker himself is clearly infatuated by the listener whom he wants to persuade. This speech plays with the listener, who probably realizes but accepts the pretense of the speaker to be a non-lover, and with the reader, who might not accept but is amused by the arguments and the particular twist in approach to the topic presented in the speech. In other words, Plato's depiction of a 'Lysianic' speech in the Phaedrus lays particular emphasis on what is later assumed to be the two particularly

5I This level of abstract argumentation is even more explicit in the 'palinode'. 
Lysianic features in speeches: ${ }^{52}$ first, the emphasis on the characters of the speech, which plays a central role in the argumentation, ${ }^{53}$ and secondly the amusing playfulness or superficiality of the speech, which is reached by not actually pursuing the arguments in any serious and thorough way, but by simply evoking different examples or commonplaces that are loosely twisted to fit the point. In order for the speech to pass among Plato's readers as potentially Lysianic, it must have exhibited some characteristic features of Lysias' writerly skills that were already acknowledged by Plato's time. ${ }^{54}$ Thus, Lysias' reputation for character delineation and amusement may well have been already established at least in some intellectual circles of the fourth century BCE. Be that as it may, Plato's portrayal of Lysias in the Phaedrus launched a tradition in the interpretation of Lysias, and all subsequent associations of Lysias with the allure and playfulness of rhetoric probably go back, in one form or another, to Plato's dialogue.

\subsection{After Plato}

Plato's possible rivalry with Lysias was picked up by at least one ancient reader - Diogenes Laertius (henceforth DL), who points out in a list of Plato's innovations that Plato was the

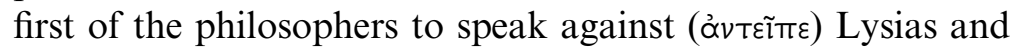
to record the latter's speech verbatim in the Phaedrus (3.25: Kai

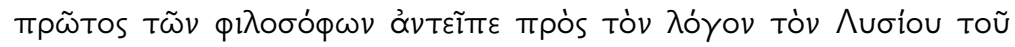

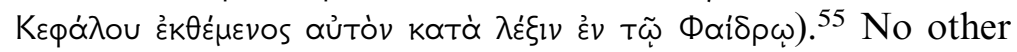
orator or rhetorician is mentioned in a context of direct rivalry with Plato, and it is remarkable that the importance of the

${ }^{52}$ Usher (I976), 33, following the debates around Dover (I968), has tried to identify the 'Lysianic' in Plato's language use, but I find his conclusion unsatisfactory as it gives us too narrow an understanding of Plato's stylistic criticism of Lysias.

53 It is, I would argue, due to our reading of the character of this 'Lysianic' speech that we do not take its argument seriously and consider the speaker as merely wanting to persuade the boy to give him sexual gratification.

54 In fact, Diogenes Laertius (see below) certainly regarded the speech as a genuine work by Lysias and the Phaedrus as depicting a confrontation between Plato and Lysias.

55 For DL I follow the recent edition by Dorandi (2013). 
Phaedrus seems to lie for DL in the fact that it is the first to challenge and analyze Lysias. ${ }^{56}$ It could of course be argued that DL is simply thinking of the beginning of the dialogue and is not really a reliable source for the contemporary reception of Lysias (be that in Plato or in other authors). However, this is a valuable reminder that Plato's Phaedrus had a very crucial role to play in the reception of Lysias. Interestingly, Lysias and his father Cephalus feature also in the list of works reported for the next head of the Academy, Speusippus, ${ }^{57}$ even though we cannot really say much more about the significance of this. ${ }^{58}$ It is perhaps surprising that as far as we can tell Lysias is not explicitly mentioned by Aristotle nor is he given much attention to in the subsequent Peripatetic tradition. ${ }^{59}$ Aristotle's possible stylistic allusions to Lysias do not enable us to say much more about his engagement with Lysias. ${ }^{60}$

${ }^{56}$ As Tarrant points out (2000), I27, however, we know from Proclus that a number of Platonic works were once seen primarily as dialectical attacks on opponents, and among those works Phaedrus was considered as a direct attack on Lysias.

57 In Dorandi's (20I3) edition of DL, the works of Speusippus are listed in 4.4.45-74.

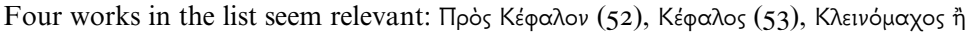

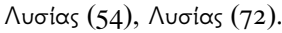

${ }^{8}$ Tarán (I98I), I 3 comments that 'like Plato Speusippus was interested in the family of the orator', and Dillon (2003), 34 agrees that the titles suggest that Speusippus was probably 'dramatizing the well-known orator (whom he would have known) and his father [...], but what these dialogues were about escapes us entirely'.

59 Carey (2007), vi suggests that Aristotle quotes directly from a speech later attributed to Lysias and refers to Lysias implicitly in three passages of the Rhetoric. The direct quotation is found in Rhetoric I367bI7-I 8 and the three other passages where Aristotle might be alluding to Lysias are: I399bI5 alluding to Lysias 34. I I, I4II I I-3 alluding to Lysias 2.6o, and I420b2-3 alluding to Lysias I2.IOO. Blass (I 887), 386 reminds us that Aristotle's omission of Lysias in his Rhetoric is not that surprising as he tends to bring examples mainly from epideictic speeches. From our previous examination of the Platonic material, however, I believe sufficient evidence was evoked to suggest that Lysias at the time was not necessarily well known only for his forensic speeches.

${ }^{60}$ In I420b2-3, which is the very last sentence of the Rhetoric, Aristotle discusses an appropriate conclusion to a rhetorical speech and gives an example of an effective

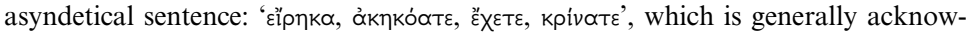

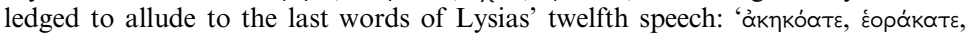

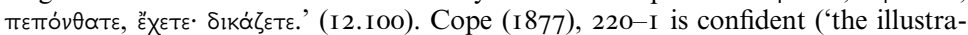
tion is doubtless a reminiscence') that this quotation refers to the closing words of Lysias' twelfth speech. If this is so, then Aristotle's choice of concluding his treatment on rhetoric (which uses mainly examples from epideictic rhetoric) with a paraphrase from Lysias' forensic speech must have been felt as an acknowledgement of the effectiveness of Lysias' style. 
The only Peripatetic who seems to have taken more interest in Lysias, or whom we at least know discussed Lysias explicitly in his work(s), was Theophrastus. Unfortunately, however, Theophrastus' views on Lysias are completely lost save for an out-of-context quotation in Dionysius' essay Lysias, where he quotes a passage from Theophrastus' On style (fr. 692 Fortenbaugh) in order to then contest the latter's views on Lysias. ${ }^{6}$ Based on a speech that Dionysius did not consider authentic, Theophrastus had apparently counted Lysias among those who are overly keen on antitheses, balanced structures and suchlike; a writer who strives for crude and overdone wording and chases after poetic effect rather than realism (fr. 692.2-3). As a response, Dionysius points out that this speech is simply not written by Lysias. In any case, the absence of any more serious engagement with Lysias in Peripatetic sources seems to indicate that a considerable difference was felt to exist between Lysias and Isocrates: while Lysias is not mentioned even once in the Rhetoric, Isocrates is the most frequently quoted contemporary author in Aristotle's Rhetoric. $^{62}$

Lysias is indeed more often compared to Isocrates and most famously so in Plato's Phaedrus, which is the only extant work until Dionysius of Halicarnassus' critical essays in the first century ВСE where the two authors are explicitly compared. ${ }^{63}$ Perhaps there are further reasons than we know of for Plato to play the two against each other in his dialogue. It is quite

Scholars have recognized two further allusions to Lysias: in 2.23.I9 (I399bI5-I7) Aristotle brings an example of enthymeme and, without acknowledging the author, the verbal similarity suggests an allusion to Lysias 34. Book 3.7 (I4I I a32-I4I I b2) seems to contain yet another allusion to Lysias, this time to his funeral oration (2.60). See Carey (2007), vi.

${ }^{61}$ For Theophrastus' On style I follow Fortenbaugh's edition (I992) and commentary (2005).

${ }^{62} \mathrm{Cf}$. Benoit (I990), 252. In fact, as far as I can tell, Isocrates is the second (only after Socrates) most frequently mentioned author in the whole work.

${ }_{63}$ There is an interesting connection mentioned in Ps. Plutarch $X$ orat. 836c, where Isocrates' student Philiscus ( $\Phi_{\curlywedge} \lambda \lambda_{i \sigma \kappa o s} \delta$ 'lбokpótous $\mu \varepsilon \dot{v}$ ), also a friend of Lysias

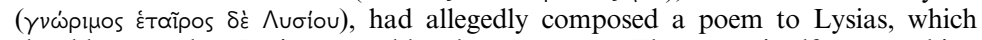
should prove that Lysias was older than Isocrates. The poem itself says nothing about the relationship between Lysias and Isocrates and it is unclear how this poem could prove the relative chronology of Lysias and Isocrates. 
plausible, for instance, and has been tentatively suggested by some scholars, that there was a personal rivalry between them. ${ }^{64}$ Whitehead goes as far as to propose that Isocrates abandoned his logographic activity due to the unsurpassable success rate of Lysias, ${ }^{65}$ and even though it is impossible to prove with any certainty, this view is quite appealing. Isocrates remains very skeptical and negative throughout his career towards speechwriters, and as far as our evidence from Plato goes, Lysias seems certainly to have been among the most accomplished speechwriters of his time. Todd points out two sets of speeches in which Lysias might have written the defense and Isocrates the accusation speeches: Isocrates' Against Euthunous (speech 2I) and Lysias' defense On behalf of Euthunous against Nikias (speech 57-8, fr. I I7-I9); Isocrates' accusation speech Trapezitikos and Lysias' Trapezitikos (speech I34, fr. 285), which has been argued to have been the defense speech from the same trial. ${ }^{66}$ In both cases Lysias is associated with the defense and Isocrates with the accusation speech. We have also fragments from a speech allegedly written by Lysias that seem to have been directed against Isocrates - тро̀ 'lookpótпv aikías (fr. I78-9 Carey, preserved in Pollux 8.46 and Photius II.236). It is unclear who delivered

${ }^{64}$ Trevett (I990); Whitehead (2004), I65-8; Todd (2007), 3I-2. Cicero's Brutus also provides potentially relevant evidence: Cicero claims (Brutus 63) that according to Aristotle Lysias was not very successful in teaching rhetoric and for this reason took up 'merely' writing speeches for others. In this sense, there is a curious similarity and contrast between Lysias and Isocrates: both arrived at their profession by a personal failure in another aspect of the discipline, Lysias in teaching or theory of rhetoric, Isocrates in practice of rhetoric; they are thus exactly opposed in their abilities and character. Further to Cicero's claim, Blass (I 887), 382 analyzes Dionysius's assessment of Lysias and argues that when Dionysius claims that Lysias never repeats his introductions and is always innovative, this could be associated with the fact that Lysias is not interested in the topoi or commonplaces that one could/would use to structure the speech; his speeches seem to draw in most cases from the underlying situations rather than from theory or textbook formulas.

65 Whitehead bases his hypothesis on [Plut.] X orat. 836a.

66 Trevett (I990) analyzes this evidence closely and goes against the commonly held view according to which Lysias' Trapezitikos was the mistake of a copyist, who confused Isocrates and Lysias, hence suggesting that there actually was only one Trapezitikos, that of Isocrates. Trevett examines the existing evidence and concludes that it is highly plausible that there were two speeches: Isocrates' accusation speech and Lysias' defense. 
this speech (and of course, Lysias' authorship is anything but certain), but it could still be used as evidence for the perceived antagonism between the two, even if the historical accuracy of this source is dubious. ${ }^{67}$ In other words, even though we have no other source for the two writers being played against each other in their fourth-century BCE reception, there is some evidence that suggests that there might have been some antagonism between the two, ${ }^{68}$ not least because, a point made in Plato's Phaedrus, they advocated completely different approaches to rhetoric.

We have seen thus far a number of important aspects about Lysias and what he came to mean for rhetoric. It is important to acknowledge, first of all, that there is little evidence of Lysias outside his own works and those of Plato, which requires anyone reconstructing Lysias' legacy to depend heavily also on Plato's philosophical dialogues. Since the influence of the Phaedrus on the rhetorical tradition was enormous (as will be demonstrated throughout this book), it is very difficult to find independent evidence for Lysias' importance for his contemporary rhetorical and oratorical scene that does not draw explicitly on either Lysias or Plato. The claim, for example, that Lysias was very popular or even the best writer of the time depends solely on the description of Lysias by Phaedrus in the dialogue, and we have no other independent evidence to back this up. ${ }^{69}$ It seems reasonable enough to accept it, but we should always be careful about generalizing

${ }^{67}$ A further, if rather spurious, link between Lysias and Isocrates is suggested in DL's list of works by Antisthenes. According to some manuscript readings, Antisthenes

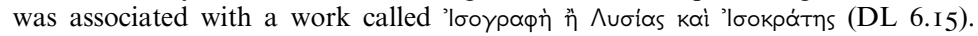

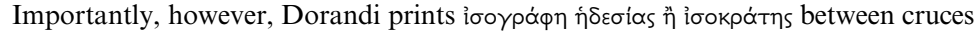
(20I3), 4I5. Either way, if there ever existed such a work it is impossible to know what this piece might have been about. Yet, if there is some validity in the title of some of the manuscripts, then this might count as another source which brings together Lysias and Isocrates on the topic of writing, perhaps regarding the two as best representing contemporary writing culture in Athens.

${ }^{68}$ It is true that their oratorical activity seems to overlap for a very short period, if we assume that Isocrates engaged in his speechwriting activity prior to opening his school in the 380 s.

69 Dionysius of Halicarnassus' later testimony seems to be wholly dependent on Plato's Phaedrus (see more below). 
such claims from our meagre outside evidence. In other words, Plato's early reception of Lysias left an immense mark on Lysias' future reception, simply through there being no other surviving external evidence.

What is, then, the image that we get from this early reception of Lysias? Lysias' own speech I 2 clearly offers an attempt to shape his image in pro-democratic and popular terms, either to win benevolence from his audience (real or imagined) at the post-Thirty euthunai trial against Eratosthenes, or to shape his reputation as a democratic writer whose services could be sought by those needing to shape up their court cases. Or both. Plato's reception clearly undermines this image and consistently portrays him as enjoying the company of morally questionable political players. This interpretation resulted from a rather meticulous and subtle reading of Plato's characterization and, as such, might have been missed by ancient readers as it certainly has been missed by most modern scholars. ${ }^{70}$ But Plato's reception of Lysias overtly challenges Lysias' reputation as the most accomplished writer of the day (as Phaedrus claims in 228a) and offers as support a critical analysis of Lysias' technique, pointing out all rhetorical faux pas and missed opportunities. Plato gets his hands dirty and demonstrates here in detail how criticism ought to be conducted, and it is in these passages that he has made an invaluable contribution to the rhetorical tradition. Equally important is the fact that Plato does not only stop there, but also offers possible improvements, here in the light of two additional speeches that he constructs in the Phaedrus in order to overcome the errors of Lysias. The latter becomes, eventually, a representative of a kind of rhetoric that makes no claims for moral improvement and invites itself to be assessed solely on the basis of style.

Plato's Phaedrus uses, then, the figure of Lysias in two separate but related ways: first, Plato makes suggestions about

${ }^{70}$ An exception here is Nails (2002), I39 who notices that 'Each time we meet Lysias s.v. in a Platonic dialogue, he is mentioned in the company of other politically inclined rhetoricians like himself, notably Thrasymachus s.v., but also Clitophon s.v., whose political allegiances, like those of Epicrates, varied over time.' 


\section{After Plato}

Lysias' intellectual circle and alludes to the moral depravity of the orator and, by implication, of the kind of rhetoric that he promotes. This is, in essence, an ad hominem attack on Lysias. An analysis of Socrates' second speech in the Phaedrus, which aims to correct the stylistic and structural mishaps of the first, but retain the argumentative core, shows clearly the unacceptable moral dispositions that underpin Lysias' rhetoric. Socrates reacts in horror and is forced to deliver a palinode. The conclusion seems to be that rhetoric ought not to be conceived in a moral vacuum and Lysias has to be informed of the implications and directed to a correct path $(278 \mathrm{c})$. Secondly, Plato constructs Lysias as a representative of a kind of rhetoric and singles him out from a wide array of writers and rhetoricians mentioned in the dialogue. Lysias is highlighted from all the rest and the speech Plato writes on his behalf becomes a generalizing, and hugely influential, account of rhetoric as style. 